Politics in Central Europe

(ISSN: 1801-3422)

Vol. 11, No. 1

DOI: $10.1515 /$ pce-2015-0001

\section{Corruption Perception in the Czech Republic}

\author{
VLADIMÍR NAXERA
}

\begin{abstract}
This paper is focused on the issue of corruption perception in the Czech Republic. After introducing the general framework for corruption perception in post-communist countries, this paper uses the Czech Republic as an example of the ways in which corruption is perceived, the areas Czech citizens feel are most plagued by corruption, and the ways in which corruption perception has transformed in terms of post-communist developments. This paper points out the differences in corruption perception among Czech citizens, the media and political parties and their representatives. The conclusion of the paper attempts to answer the question of how corruption perception has affected the overall perception of the democratic regime in the Czech Republic. It also asks questions regarding how this has influenced the evaluation of democracy and the relationship between Czech citizens and political institutions, including individual political parties.
\end{abstract}

Keywords: corruption, corruption perception, CPI, Czech Republic, attitudes towards regime

\title{
Introduction
}

One of the main questions regarding the research of the topic of corruption is the perception of corrupt behavior. This deals with both public and political representation. Many existing studies show that these two discourses are often fundamentally different (Karklins 2005; Uslaner 2008a; Uslaner 2008 b et al.). Corruption perception is the subject of various research projects, while the Corruption Perception Index (CPI) holds an exclusive place among published research results on the topic. The CPI is published annually by Amnesty International. Various other international studies are carried for example by Eurobarometer, which publishes several reports focused directly on corruption.

This paper will focus on corruption perception in the Czech context. The topic will first be discussed in the general framework of corruption perception in the post-communist environment in general, and will then shift its attention to the Czech Republic. Based on existing research and our own analysis, the goal of the 
paper will be to present corruption perception and the various transformations it has undergone, all on various discourse levels (discourses of the public and the media; discourse created by political parties and their representatives). The final section of the paper will focus on a wholly fundamental topic - the way corruption perception affects the assessment of the Czech democratic regime and its operation. It will also focus on the transformation of voter support depending on the degree of emphasis on the topic of corruption. The paper has not been conceived chronologically but rather in a thematic order. A chronological approach will be applied only under individual thematic sections.

\section{A note on corruption perception in post-communist countries}

In communist countries, including Czechoslovakia, corruption was rampant. One of the reasons many researchers (compare Sandholtz - Taagepera 2005; Åslund 2007; Sajó 2003; Holmes 2003 et al.) have assumed the opinion that the fall of communism actually led to a greater degree of corruption may be that their perception of it has changed - some phenomena that were not previously viewed as corruption or clientelism began to be called so under new post-communist conditions. Moreover, the media, which freed itself from party surveillance and censorship, was allowed to report on phenomena that would otherwise have depended on the party's will. This is perhaps an explanation for the ostensible view that "corruption is all around us", despite the fact that the degree of corruption may not actually have risen since communist times. There has been a fundamental difference in the situations of the old and new regimes. Together with this, a difference has also arisen between old and new corruption discourse (compare e.g. Karklins 2005).

Research carried out in various post-communist countries with a differing degree of economic standards and differing political development has shown similar corruption perception (Uslaner 2008 b). Research in all cases has confirmed not only the different perception and evaluation of so-called "small" and "big" corruption, it has also shown differing corruption perception in terms of the political elite and the public. Research has also pointed out the connections between corruption perception, economic equality or inequality, and overall trust in institutions and society in general. In terms of this research, citizens of individual countries viewed the degree of corruption as higher than did high-ranking state officials and political leaders. In public discourse, corruption has resounded more emphatically than in the discourse of the elite. The public often points out high political corruption as one of the main problems. Even in Estonia, which long holds the best position among post-communist countries in the Corruption Perception Index (see Table 1), people believe that high political corruption is a common phenomenon (Uslaner 2008 b; Karklins 2005). Both the public and the elite believe there is a high level of small-scale 
corruption (Uslaner 2008 b: 160). In certain cases, the public's belief that the elite are corrupt is sometimes used to justify their own involvement in small-scale corrupt transactions (Karklins 2005: 59).

\section{Table 1: Corruption perception index in selected post-communist countries in the years 2008-2013}

\begin{tabular}{|c|c|c|c|c|c|c|c|c|c|}
\hline & EST & PL & LT & H & LV & CZ & SK & RO & BG \\
\hline $\mathbf{2 0 1 4}$ & $26 / 69$ & $35 / 61$ & $39 / 58$ & $47 / 54$ & $43 / 55$ & $53 / 51$ & $54 / 50$ & $69 / 43$ & $69 / 43$ \\
\hline $\mathbf{2 0 1 3}$ & $28 / 68$ & $38 / 60$ & $43 / 57$ & $47 / 54$ & $49 / 53$ & $57 / 48$ & $61 / 47$ & $69 / 43$ & $77 / 41$ \\
\hline $\mathbf{2 0 1 2}$ & $32 / 64$ & $41 / 58$ & $48 / 54$ & $46 / 55$ & $54 / 59$ & $54 / 49$ & $62 / 46$ & $66 / 44$ & $75 / 41$ \\
\hline $\mathbf{2 0 1 1}$ & $29 / 6,4$ & $41 / 5,5$ & $50 / 4,8$ & $54 / 4,6$ & $61 / 4,2$ & $57 / 4,4$ & $66 / 4$ & $75 / 3,6$ & $86 / 3,3$ \\
\hline $\mathbf{2 0 1 0}$ & $26 / 6,5$ & $41 / 5,3$ & $46 / 5$ & $50 / 4,7$ & $59 / 4,3$ & $53 / 4,6$ & $59 / 4,3$ & $69 / 3,7$ & $73 / 3,6$ \\
\hline $\mathbf{2 0 0 9}$ & $27 / 6,6$ & $49 / 5$ & $52 / 4,9$ & $46 / 5,1$ & $56 / 4,5$ & $52 / 4,9$ & $56 / 4,5$ & $71 / 3,8$ & $71 / 3,8$ \\
\hline $\mathbf{2 0 0 8}$ & $27 / 6,6$ & $58 / 4,6$ & $58 / 4,6$ & $47 / 5,1$ & $52 / 5$ & $45 / 5,2$ & $52 / 5$ & $70 / 3,8$ & $72 / 3,6$ \\
\hline
\end{tabular}

Source: Transparency International (n. d.)

Survey results from 1997-1998 show that a significant portion of citizens of post-communist countries have experienced a request for a bribe by a public official. One of the Index's conclusions shows that a public official asked for a bribe directly only rarely. Requests for providing a bribe were usually carried out in the form of hinting (Karklins 2005: 42; compare Miller - Grodeland Koskechkina 2001: 85), which provides more proof of the wide-spread nature of "corrupt norms" 2 - if corruption has permeated society to such a degree, it is not necessary to ask for a bribe explicitly.

1 Information is listed by country in terms of total scores.

2 Corruption as an element of the social system has its own rules of the game; it has its own development mechanisms, etc. According to some authors (Frič 2001: 66), corruption can lead to the spread of a "corrupt climate". This refers to a set of collective concepts and cultural models that for citizens turns corruption into an obvious and customarily justifiable fact and form of legitimized behavior (Frič 1999). If citizens were to formally respect the valid system of laws and rules, it would significantly slow the spread of corruption. In countries with a functioning civil society and respect for norms, corruption is understandably less wide-spread (compare Putnam 1993). When we look for example at the development of Czech society, we see that for a long time, an opposite model of sorts has been in effect, based on which the giving or acceptance of bribes is viewed as common behavior (Frič 1999: 73-74). If we mention the question of respect for norms, in communist Czechoslovakia we would paradoxically find respect (or consent) for corrupt norms, which made up an unofficial set of cultural norms that were in contradiction to the norms officially espoused by the state and party institutions. The spread of a corruption climate in Czech and other environments is not the simple result of the drastic transformations that took place after the fall of the communist regime, but was created during the operation of the former regime. The repetition of corrupt behavior creates norms of corruption, which then guide corruption and spread it through society. Without taking the relevant context into account, it is impossible to exclude the individuals taking place in corruption from these rules, norms and relationships, just as it is impossible to study corruption without these factors. 
In all of the countries analyzed, however, the view of the public and the elite are inconsistent in the evaluation of small-scale corruption - although both sides see this form of corruption as being wide-spread, the public often sees it as acceptable and does not link this to an overall mistrust of the system and its institutions (contrary to large-scale corruption). To the public, it is thus a common phenomenon that has been internalized and is easily justifiable when challenged (Karklins 2005: 67). This will be dealt with later in the paper in connection with corruption perception in the Czech Republic. In this context, Pavol Frič (1999; Frič - Kabele 1999) emphasizes the influence of the communist regime, which gave rise to a deeply-rooted corrupt climate in society.

Contrary to this, the elite views small-scale corruption as wholly unacceptable. In this issue, the elite show a higher level of trust in members of the police force than does the public, who view bribes given to police officers as being a relatively common occurrence (Uslaner 2008 b: 160; Frič 2001; European Commission 2013). Although the elite often condemn small-scale corruption, it is often not incorporated in official measures and, despite their verbal campaigns, they also end up tolerating this type of corruption as well. This leads to a state in which the elite, based on differentiation between what is "normal" and what is "deviant" in a certain society, define the boundaries of corruption. In some situations this can be linked to the realization that for some lowly-positioned officials, these forms of corruption can actually be a necessary condition for economic survival. In general, such a state shows that the norms accepted during transformation have not actually been internalized by the elite (Green - Ward 2004: 15; Holmes 2003; compare Berger - Luckmann 1999). Another finding shows a difference in opinion in terms of the growth or decline of corruption - while the elite often answer in surveys that they view the degree of corruption as being the same or lower than it was in the communist era, the public explicitly expresses the opinion that corruption has significantly grown since the fall of communism. This public view that political corruption has grown significantly since the end of the communist era has been confirmed by other research findings (e.g. Haukanes 2004).

\section{Corruption perception in the Czech Republic}

If we look in greater detail at the Czech Republic, we may claim that in the initial post-communist period, i.e. in the first years of the existence of Václav Klaus's government, corruption (despite the evident awareness of corruption issues during the period of transformation) was not a common topic of official government statements (Reed 1999a: 161). When it was discussed, its importance was often belittled. ${ }^{3}$ A common argument in Czechoslovakia/Czech Republic has been the

3 This is evident in the example of corruption linked to privatization. Despite many indications and proof of corruption, many government leaders were long unwilling to admit the problem or simply made light of it. We can cite a famous quote here from Václav Klaus, who defended the method of privatization 
claim that corruption is the price that must be paid for a quick transformation into a privatized state. Over the course of time, however, corruption became an integral part of political statements and documents on all various levels, ${ }^{4}$ while political leaders began to express their willingness in declarations on dealing with corruption. The topic of corruption thus became an integral part of the public debate. Corruption perception has been changing, which is evident in both political statements and for example in the frequency of media coverage on the topic. In the example of the Czech Republic, we have seen a tendency since the $1990 \mathrm{~s}^{5}$ to the present toward a qualitative transformation in terms of references to corruption. Since the middle of the $1990 \mathrm{~s}$, in the press and on public television, the number of reports dealing with corruption has dominantly risen. In Czech Television broadcasts in 1996-1997 the topic was still almost non-existent; later, however, there began to be more and more programs covering the issue.

In terms of printed media and television, there was a period of growth for reports and articles on the topic of corruption, followed by a slight decline (in the press in 2007-2009, on Czech Television 2008-2009), replaced again by an increase that culminated in 2012, when the number of articles began to grow primarily due to the case of the arrest of former Central Bohemian regional governor David Rath. A case involving three members of parliament belonging to the former Civic Democratic Party (ODS) Peter Tluchoř, Ivan Fuks, and Marek Šnajdr also drew attention. ${ }^{6}$ In addition, there were several other highly covered scandals involving military purchases accused of exaggerated prices and other controversies linked to commissions for public procurements. Data points to two interesting factors: Firstly, all four nation-wide newspapers (MF Dnes, Právo, Lidové Noviny and Hospodářské Noviny) show a very similar trend in the increase or decrease in the number of articles dealing with corruption (with the exception of MF Dnes, which has a higher number of articles on this topic but shows a similar trend). Secondly, although the years 1998-2002 are generally perceived to be periods that gave rise to corruption and clientelism

despite corruption scandals with the following: "If over a certain interval of time hundreds of thousands of cars drive down a highway and several dozen of them crash, it is quite sad, but none of us would call it a complete failure of the roads system" (Klaus cited in Reed 1999 b: 157).

4 The necessity to combat corruption and remove old "corrupt elites" has appeared as one of the flagship issues in the programs of newly formed and (albeit perhaps only temporarily) politically successful parties (e.g. Věci Veřejné, ANO).

5 The archive of the Anopress IT database, from which the date below was taken, dates back only to 1996.

6 According to the Public Prosecutor's Office, these parliamentary deputies accepted a bribe in the form of lucrative posts in state-run companies as reward for giving up their mandate and thus not taking part in the negotiation of a law on which they had an opinion that differed from their party and the whole governing coalition. These "exchanges" for leaving their posts were supposedly offered to them by then Prime Minister Petr Nečas. Based on a decision of the Supreme Court of the Czech Republic, however, these three MPs were cleared of all accusations with the justification that they cannot be prosecuted for alleged criminal acts that took place before they gave up their mandate - the acts of these MPs were thus protected by immunity held by deputies (more in Naxera 2014; Kupka - Mocht́ak 2014). 
(Kopeček 2013: 295), we see no significant increase in reports in these years dealing with corruption as compared to other periods.

\section{Graph 1: Development of references to corruption in national newspapers and public television (1996-2013) ${ }^{7}$}

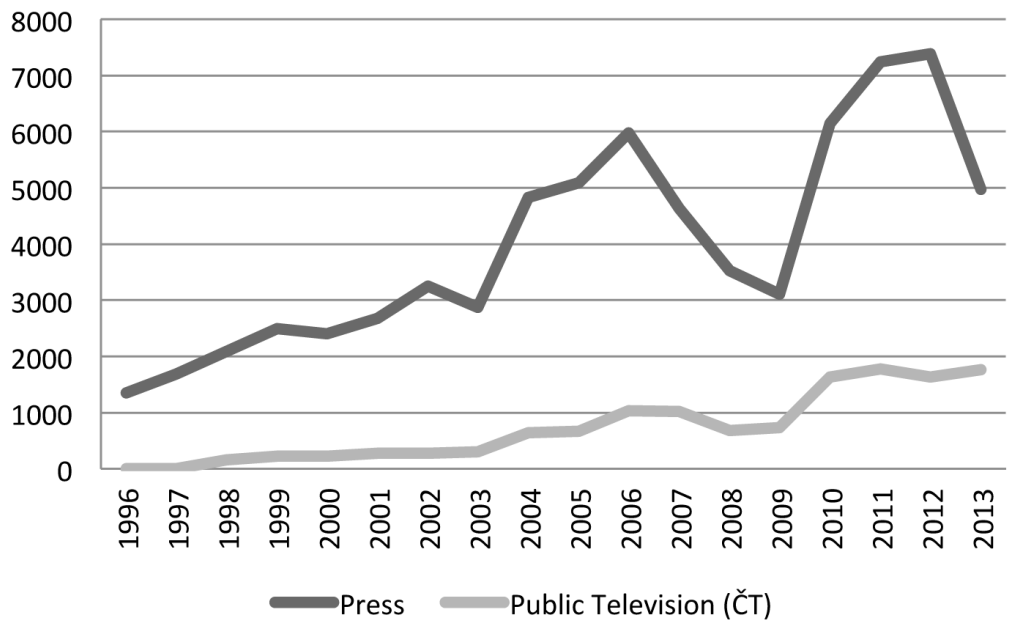

Source: Author

\section{Graph 2: Development of references to corruption in national newspapers $(1996-2013)^{8}$}

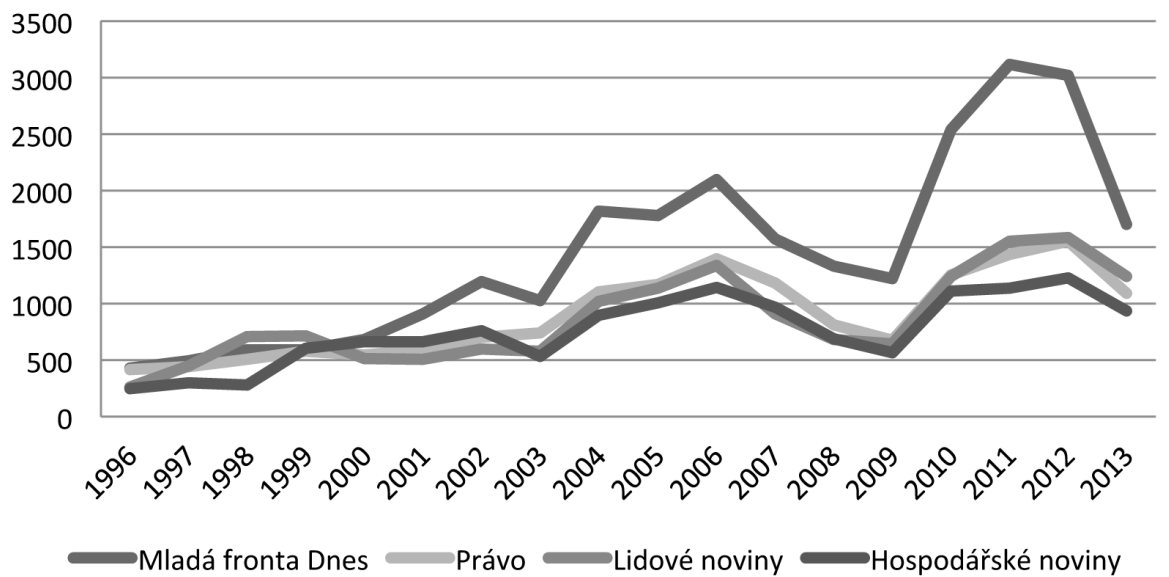

Source: Author

7 The graph depicts the number of articles in newspapers (total numbers of MF Dnes, Práva, Lidové Noviny and Hospodářské Noviny) and reports on public television (the total number of all Czech Television channels combined) that contain the words "corruption", "corrupt", "bribe" or "clientelism".

8 The graph depicts the number of articles containing the words "corruption", "corrupt", "bribe" or "clientelism". 
In public opinion polls that were carried out in the Czech Republic at the end of the 1990 s (see Frič 1999: 77), a large portion of the public failed to mention corruption as one of the three most serious problems of Czech society despite the high amount of corruption scandals that had taken place throughout the decade. This also corresponds to the less than thorough attention paid to corruption by the political elite of the time. ${ }^{9}$ In addition to a weak civil society, for which passivity and indifference (e.g. Vráblíková 2009) are characteristic, the influence of a corrupt climate is also greatly responsible for such a situation. In surveys (compare Frič 1999), a large portion of respondents give answers that suggest that taking and giving bribes in the Czech Republic is something deeply rooted, the tradition of which reach far back into the past. The pressure of corrupt norms is so evident that many people give bribes "out of habit" without the bribed party even having to make the request for one. This deals mostly with small-scale bribes in the form of "presents" or "kickbacks". A large number of people thus think that although corruption is not evident superficially, corrupt norms exist in society and providing bribes is often considered to be a necessary condition for success (Frič 1999: 79). Many of these small-scale bribes (e.g. a bottle of alcohol or a box of sweets for the doctor) has been so encoded into society that the majority of its members do not even see it as corruption but rather as a gesture of politeness. In this sense, roughly three quarters of respondents in surveys conducted at the end of the 1990 s expressed their experience with giving "gifts" (Frič 1999: 79; Ondráčka in Česká televize 2011). This is also reflected in more recent surveys, which show that respondents are far more willing when requiring a service from authorities to provide a reciprocal service or "gift" rather than money. While $53 \%$ of respondents considered a reciprocal service to be acceptable, $47 \%$ considered a gift to be acceptable, while only $19 \%$ chose money. We should add here that in these categories, the statistics from the Czech Republic are far higher than the EU average, mainly in the case of reciprocal services and gifts (compare European Commission 2013: 2). ${ }^{10}$

9 Newer research now shows different results (compare below).

10 Some practices in terms of small-scale corruption have been ingrained so deeply into society that it does not actually link them to corruption at all. However, bringing a "small gift" to one's doctor or official in public services is a completely different act than bringing a present to friends while on a visit. The principle of gift giving in a liberal democratic society has its place exclusively in the private sphere (see Müller 2012a). Giving of gifts in the public sphere can lead to the feeling of creating obligations into the future, which violates the principles of the public sphere. Despite this fact, giving "gifts" has become routine and is very accurately illustrated in Fríc and Kabele's (1999: 22) writing, which we will quote here in full: "In the Czech Republic, there is a tale about a general practitioner who, upon his well-earned retirement, gives his successor the keys to a cellar filled from top to bottom with bottles of alcohol of all various brands. When asked embarrassedly by his younger colleague why he would do such a thing, the doctor gives him the following explanation: 'Already in my youth, I was a sworn enemy of alcohol and I have been a teetotaler ever since. What's more, I was also an idealist and I viewed bribe-taking as a humiliating, loathsome activity. At first I tried to explain this to my patients. They refused to accept my arguments, and either quickly began to buy different brands of alcohol or forced money on me. Soon, however, I was to realize that in refusing their bribes, I was insulting them and arousing generally unpleas- 
The surveys that Frič (1999) cites show us one more additional and interesting fact - the presence of a double standard. ${ }^{11}$ In the vast majority of cases, answers contained the belief that corruption is a negative and immoral phenomenon and one which the respondent would never take part in - personally accepting or giving a bribe was admitted by only $10 \%$ of respondents. Contrary to this, the vast majority of respondents state in polls that bribes are commonplace. The parallel validity of two contrasting social norms is often interpreted as one of the results of communist rule. In terms of the communist regime, using two sets of morals was an oft-used life strategy under the communist regime (compare e.g. Možný 2009; Klicperová-Baker - Feierabend - Hofstetter 1999; Holý 2010 et al.) - individuals' experience with two sets of morals (one for the public and one for the private sphere) has a history that stretches back decades.

In $2013,15 \%$ of respondents admitted to having given a bribe while in contact with providers of public services (police, public authorities, education, health care, etc.). However, $95 \%$ of respondents view corruption as a problem (Transparency International Czech Republic 2013), while the belief that corruption covering the whole spectrum of state institutions and authorities dominates public opinion. The vast majority of respondents is also convinced that the degree of corruption has been growing in recent years (European Commission 2013: 1). If we move our attention from small-scale bribery and corruption and focus on the level of public authorities, the public debate often reflects the belief that "the elite are corrupt" and should be replaced. ${ }^{12}$ Also, the debate on the necessity of combating large-scale political corruption can be noticed always after the revelation and media coverage of corruption among highly positioned political leaders - recently, this happened with the three previously mentioned former ODS deputies. "A crucial problem [in terms of corruption perception among the Czech population] is not in the abuse of power by lower-level officials in providing public services, but the abuse of public funds through the manipulation of public procurement and other various grants. The link between business, political representation and high-ranking members of the state administration play a key role"

ant feelings. This included their mistrust and the suspicion that I might not be such a good doctor if I did not request the same compensation as the others, who were also truly good doctors. In order to defend my good name, I had to adapt - the result of which is this cellar full of alcohol, which I personally want nothing to do with."

11 According to Jeanne Becquart-Leclercqové (1989), a dual normative structure is actually characteristic of every society or, more exactly, in every societal grouping. One set of morals corresponds to the world of ideals, while the other arises from confrontation with reality. If both structures begin normatively to overlap, a situation arises that is beneficial for society - reality thus is created according to what the majority of citizens expect. On the contrary, if the difference between these two structures is vast, it means that public proclamations and actual operations are completely different. A good example of this can be found in communist regimes.

12 Because of this, we often see the appeal to replace the corrupt elite voiced by new political parties striving to gain entrance into parliament (e.g. the case of the Věci Veřejné party or Adrej Babišss ANO movement). 
(Transparency International Czech Republic 2013). This belief is significantly reflected in the perception of the function of a democratic regime (compare Linek 2010). Author Vladimíra Dvořáková (2012: 12) embodies this form of "people's debate"13 in a chapter of her book: "I know (even from my own experience) that all of these clientelist networks fight to defend themselves tooth and nail from being defeated. Anyone who blows the whistle on corruption and clientelism or uncovers its abuses must be punished. That is their [i.e. corruption politicians'] form of prevention, which is aimed at prohibiting and intimidating."

A large portion of society is convinced of the previously mentioned link between business and politics - 69\% of respondents in 2013 replied that clientelism and nepotism in the public sphere and its higher echelons was damaging to business. This corresponds to an older poll by the Association of Small and Medium-Sized Enterprises and Crafts CZ from 2010, in which 60\% of questioned businessmen stated that it was not possible to win a public tender with corruption or acquaintances in the proper places (Transparency International Czech Republic 2013; compare also Czech Television 2011). In addition to this link between business and politics, a large portion of respondents in the Czech Republic are convinced of the illegal financing of political parties - in this sense, $81 \%$ of respondents voiced this opinion (Transparency International Czech Republic 2013). This number was similar in polls done again in 2014 (CVVM 2014 b).

Perception of the spread of corruption in the Czech Republic has strengthened since 2009, when the Czech Republic dropped several notches in the CPI ladder. It has held roughly the same position until now (see Graph 3). Belief in the corruption of the elite and the necessity to deal with this corruption, however, is not often successfully transformed into successful social action. ${ }^{14}$ This is partially due to the weakness of civil society (e.g. Vráblíková 2009; Sedláčková 2012; Müller 2012 b; Howard 2002 et al.), but is also for example caused by the widespread and often shared opinion that high political corruption must be dealt with by highly-ranking political officials and not by society (compare Karklins 2005). We should add, however, that in recent years there have been more and more civil society organizations focusing on monitoring and combating corruption (aside from Transparency International, we can name the Anticorruption Endowment, Reconstruction of the State and others) (Dvořáková 2014).

In general, corruption perception in the Czech environment corresponds to the previously mentioned general patterns that arise from surveys carried out e.g. by various post-communist countries (Uslaner 2008 b).

13 Various examples of these "people's debates" (as opposed to "elite debates") can also be found in Czech Television broadcasts (2011).

14 There are civil society organizations that have made significant efforts in the fight against corruption in previous years and which have proof of certain success in this matter (Transparency International or in the Czech context the Anticorruption Endowment). 
Graph 3: CPI in the Czech Republic (1996-2013) ${ }^{15}$

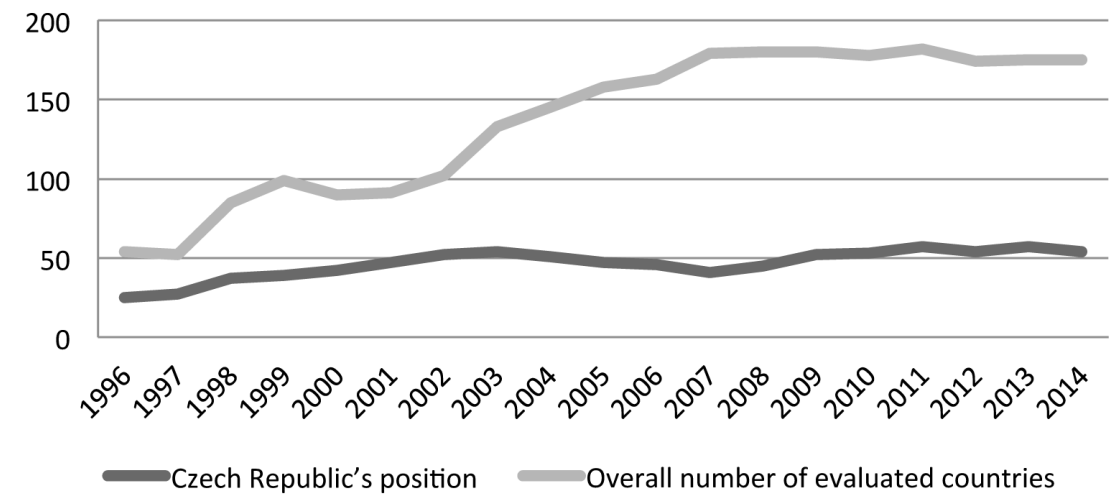

Source: Transparency International

\section{Depiction of corruption in Czech political party programs}

Corruption as a fundamental social and political issue logically also holds a place in the discourse created by political parties and their leaders. Therefore, it is exceptionally interesting in this context to analyze the programs of political parties. The following section summarizes findings on references to corruption in the programs of four political parties (ODS - the Civic Democrat Party, KDU- ČSL - the Christian and Democratic Union, KSČM - the Communist Party, and ČSSD - the Czech Social Democrat Party) which have all held long-term seats in the Chamber of Deputies of the Czech Parliament. Results come from a study of party programs created for all parliamentary elections until the year 2013 (for more on this topic see Naxera 2015). Thus, this does not provide a complete view of the stance of political parties on the topic of corruption but provides only a contribution to analyzing these stances.

By focusing on the depiction of the topic of corruption in political party programs over the course of post-communist developments and also the frequency of this depiction (see graph 4), we may draw several conclusions. In the beginning of the $1990 \mathrm{~s}$, corruption was not a topic often dealt with, although the programs mainly of left-wing opposition parties soon began to place an emphasis on linking the process of post-communist privatization of former state property to illegal financial activities including corruption, or an emphasis on linking private economic interests with public ones. Criticisms of privatization linked to corruption were still appearing in the programs of ČSSD and KSČM

15 The CPI has existed since 1995. The Czech Republic was not, however, a part of the survey in its first year. 
as late as 1998. Privatization is presented as a process that, thanks to the way it was implemented, led to the illegally-gained fortunes of a select few individuals. On the contrary, ODS (and to a certain degree KDU-ČSL) have emphasized the positive impacts of privatization while failing to mention any of its negative aspects. This also touches on the issue of corruption. This is linked to the evident "playing-down" of corruption on the part of various politicians in the beginning of the $1990 \mathrm{~s}$.

The second conclusion can be drawn in connection to the 2002 elections, which came after a four-year period of the so-called "opposition agreement", which is today commonly associated with the proliferation of corrupt behavior (e.g. Kopeček 2013). These were elections during which the emphasis on corruption first began to grow strongly. This happened mainly in the programs of parties that had been until then opposition parties, mainly the "Koalice" Party. ${ }^{16}$ On the contrary, no growth in the emphasis on corruption in ODS and ČSSD programs was logically recorded.

Furthermore, we can add that corruption is conceived in different ways according to party - for example, ODS connects corruption predominantly with small-scale bureaucratic corruption, whereas a number of other political party programs show the conviction of the systematic growth of corruption not only in state bureaucracy, but also in upper political echelons. ${ }^{17}$ At the same time, it is evident that the emphasis on corruption in higher spheres is placed by individual parties primarily in cases where they had functioned as members of the opposition in the period preceding the given election period, not as a member of the ruling government. In such cases, it is common for these parties to link the growth of corruption in the years prior to the operation of the previous government against which they had formed an opposition (these were e.g. ČSSD programs in 1998 and 2013, ODS in 2006 or Koalice in 2002). Evidently, the topic of corruption has become a tool used in the political struggle between individual parties.

The next interesting finding is linked to parliamentary elections in 2013, during which the overall emphasis on corruption among individual parties rapidly decreased (the most significant drop can be seen with ODS, which wholly avoided the topic of corruption in its program). This may in turn be linked to a number of direct or indirect corruption scandals involving high political positions (especially ODS - see e.g. Kupka and Mochtak 2014) that were highly covered by the media in previous years. This contrasts with the growth in the number of articles and reports in the media (see Graph 1 and Graph 2), which

16 Koalice is the term designating the coalition formed by KDU-ČSL and the Freedom Union-Democratic Union, which ran on the same ticket for the 2002 elections.

17 We find this statement in an ODS program in only one case in 2006. This program was designed around elections, prior to which ODS had been in the opposition for eight years, and is an exception for ODS programs in general in terms of the concept of corruption. 
culminated in 2012 (with a mild decrease until 2013), and also with public opinion polls in which $95 \%$ of respondents reported that corruption was a serious problem. In these polls, the greatest emphasis was placed on the corruption of highly-ranking politicians and other government officials; the financing of political parties; and the intertwining of business and politics (compare above, or Transparency International Czech Republic, 2013). In conclusion, we should mention that corruption as a topic was the most marginal in KSČM's programs. While mainly in 1992, 1996 and 1998 communist programs explicitly and implicitly linked corruption to the privatization process, in later periods corruption is mentioned only in brief through the use of general phrases on the harmful nature of corruption and the need to combat it. This is interesting considering that KSČM is not present in executive functions and its members are not as often linked to corruption cases in the media and therefore could strongly take advantage of the topic in terms of the political struggle.

\section{Graph 4: Quantification of the frequency of references on corruption in the} programs of selected political parties for the former Czech National Council and the Chamber of Deputies of the Parliament of the Czech Republic

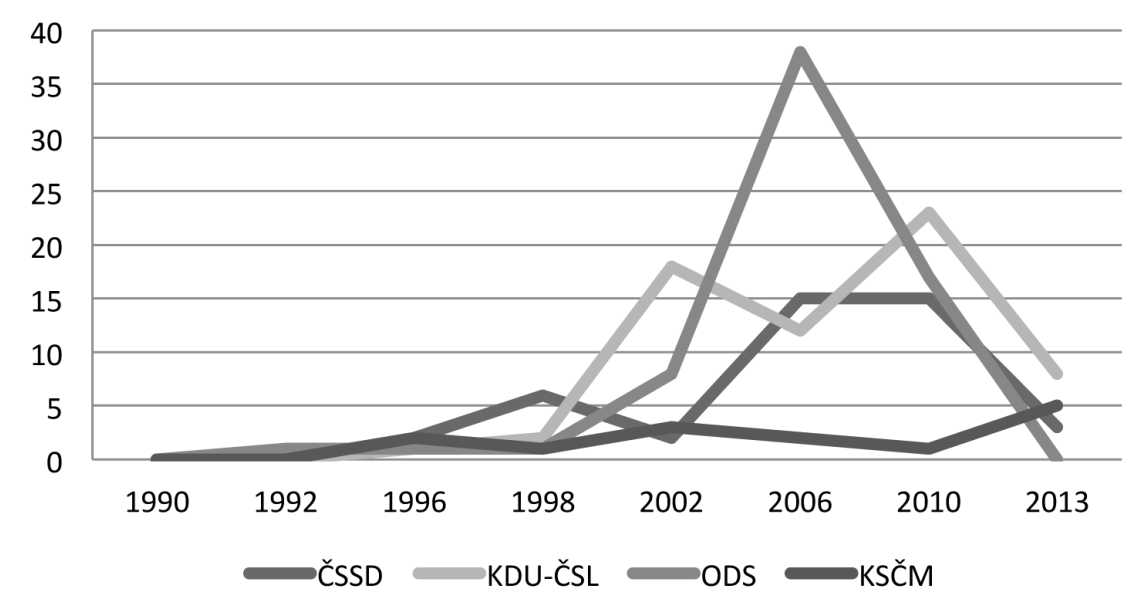

Source: Author

\section{Consequences of corruption perception for the evaluation of the political regime}

Extensive corrupt behavior brings many consequences that are commonly considered negative. Very often, the economic impacts are mentioned in reference to finances taken out of the public sector through corrupt transactions, which are then lacking in the budget for other areas where they are more needed. In terms 
of corruption perception, it is interesting to follow the impacts of corruption on the functioning of democracy and society's perception of this. Widespread corruption harms the functioning of a liberal democratic state at its very core.

For a liberal democratic society, corruption has many consequences. One of the characteristics of such a model of government should be a fairness that is perceived in terms of equality toward the state (compare e.g. Rawls 1995). By giving unfair advantage to select players, corrupt and clientelist mechanisms strongly undermine this equality. This rampant corruption, which can be found in communist regimes and in societies founded after the fall of communism, leads to the spread of corruption norms and corrupt rules of the game. Although these rules are not spread on an official level, they distinctly form or deform the official rules of "gameplay". The certain normative vacuum that exists at the moment of the fall of a communist regime and the initial phase of transformation creates an environment in which corrupt norms may strongly take root. Thanks to this, corruption has the opportunity to influence and set the direction of the development of the formal image of the political system (Scott 1972), even though this transformation of the system and its official rules has not been "consecrated" by standard methods of approval. Rampant corruption and the corruption norms that are linked to it thus limit the actual principles of democracy. The spread of corrupt norms and climates also affects corruption perception, which does not necessarily have to be viewed by society as condemnable. It can be perceived as a common tool for an individual to function in public space. If we summarize the specific expressions of violating the democratic rules of the game, we can include (1) the violation of individuals' equality in their access to the state, which leads to a drop in the trust citizens have in the state and its institutions, and (2) making it impossible for citizens to influence any changes in the operation of the system.

The political consequences of corruption are thus manifold, and include those both short and long-term (Johnston 1989). One of the short-term effects is the increase in cost, slowness, and unpredictability of official procedures. There are other long-term consequences in addition to disrupting the equality of access to the state and its services. Corruption helps to weaken trust in various elements of the political structure and, in extreme cases, leads to complete loss of trust in the democratic system and a loss of faith in the norms of a liberal democratic nation. In this context, author Lukáš Linek (2010) refers to four dimensions of negative approaches toward a regime that can be linked to corruption. These approaches include illegitimacy of the regime, institutional estrangement, individual estrangement, and political dissatisfaction (Linek 2010: 14). The first of these dimensions relates to whether an individual considers a democratic regime to be the correct or incorrect system, while the latter three deal with lower levels of evaluation of regimes and some of their specific elements. Institutional estrangement is linked to the degree to which citizens 
are convinced that political institutions react to their requests. Individual estrangement expresses the degree to which individuals feel politics affects them and how able and willing they are to take part in it. Political dissatisfaction is connected to evaluating the dissatisfaction with and mistrust of institutions, which is predominantly based on evaluating the performance of the economic and political spheres (Linek 2010: 14).

Considering all these dimensions, the question regarding the overall legitimacy or illegitimacy of a regime should be considered to be the most stable indicator from a long-term standpoint. This dimension is not so strongly subject to major short-term deviations as are the lower dimensions. This of course depends on the ability of citizens to differentiate between the legitimacy of a regime and its effectiveness. Despite some middle or long-term deviations, we can state that the support of the democratic regime in the Czech Republic has long dominated over the support of alternative models including the opportunity to return to the communist regime previous to the year 1989 (Linek 2010: 65). In terms of existing research, we can, however, see an evident shift in 1997-1998 (compare Table 2), which involved economic problems,${ }^{18}$ political party financing scandals (see also Linek - Outlý 2008; Císař - Petr 2007; Pšeja 2005) and issues connected to the "Opposition Agreement"19 (compare Linek 2010: 85; data from research see Ibid.).

Table 2: Evaluation of the functioning of the political regime in the Czech Republic 1991-2006 (percentages of positive responses)

\begin{tabular}{|l|c|c|c|c|c|c|c|}
\hline & 1991 & $1992 / 3$ & 1994 & 1995 & 1998 & $\mathbf{2 0 0 4}$ & 2006 \\
\hline Communist regime & 23 & 29 & 23 & 24 & 31 & 31 & 35 \\
\hline Current democratic regime & 71 & 71 & 78 & 77 & 56 & 69 & 63 \\
\hline
\end{tabular}

Source: Linek (2010: 65)

These three factors, i.e. the state of the economy, the problematic system of political party financing (often linked to privatization) and the signing of the Opposition Agreement, are according to author Linek (2010: 15) linked to the transformation of the lower dimensions of regime evaluation. In this context, he has elaborated on the former proclamation made by Václav Havel, who in one of his speeches deemed the yet unfinished process of privatization and the corruption of politicians and state officials as the main reasons for the dissatisfaction of the country's citizenry: "[T]here is a dominant belief that in this

18 It should be added that, after the fall of the communist regime, Czech citizens linked their expectations of democracy mainly to growth in the economic sector (compare Vráblíková 2009) - thus, economic declines can be dramatically reflected in the perception of democracy.

19 The "Opposition Agreement" was a pact formed between ČSSD and ODS on mutual cooperation after early elections in 1998. 
country it pays to lie and steal; that many politicians and state officials are bribable and that political parties - however eloquently they speak about their virtuous intentions - are secretly manipulated by suspect financial groups" (Havel 1997). The era of the opposition agreement is often linked to issues of corruption and the illegal financing of political parties (e.g. Kopeček 2013). Issues concerning such problematic methods of financing can be found even earlier - in 1997, problems mainly surrounding ODS party financing arose (compare e.g. Pšeja 2005; Linek - Outlý 2007; Císař - Petr 2007), but also included other political parties, e.g. the Civil Democratic Alliance and KDU-ČSL, who had issues with non-transparent gift-receiving and other bank loans (Linek 2010: 15).

Now we can shift our focus toward the lower dimensions named in relation to the regime and how corruption, clientelism and other similar practices affect them. Firstly, we will concentrate on the estrangement from politics, which we have divided into individual and institutional. Individual estrangement is expressed through a political passiveness that is typical for all post-communist countries (even in comparison with western societies) including the Czech Republic (for an interesting quantitative information and comparison see Vráblíková 2009). The long-term low degree of political participation immediately after the fall of communism in the first state of transformation is typical for all post-communist countries (Ingelhart - Catterberg 2002). This passiveness stems from the lack of knowledge on the function of the democratic process and also from the belief that a citizen has no ability to influence politics. In recent surveys, for example, $80 \%$ of Czech respondents voiced their opinion that Czech citizens have no realistic methods of influencing political activity or change any of the aspects they consider to be negative (Matějka 2014). "[.] civil society has no means to combat corruption. It can only disagree with it and write petitions in protest, which is like writing a resolute petition against the activities of the mafia. By doing so, some will calm their consciences and others will have a laugh at its expense" (Keller 2013: 7). Individual estrangement, the degree of which is relatively stable in the Czech environment (Linek 2010: 114), is important for corruption in that it decreases the participation of individuals in the political process, which in turn weakens the pressure from the public necessary to subdue corruption. However, we have already stated that this trend is possibly, slowly changing in some areas.

Let us then have a look at the institutional estrangement that is linked to the belief that political institutions do not react to the wishes of the citizenry and that elected political parties and politicians act as they please after being elected. According to long-term surveys in the Czech Republic, we can state that roughly $60 \%$ of Czech citizens are convinced that once politicians are elected, they follow their own interests and not the interests of the public. This is connected to the overall conviction that political parties are corrupt (CVVM 2014 b; also compare Graph 5 and Graph 6). This number (60\%) is stable in the long-term context (with the exception of the end of the $1990 \mathrm{~s}$ ) and in comparison 
with western European countries is fairly high (Linek 2010: 113). An important element that is reflected in institutional estrangement is corruption perception (Linek 2010: 14). Therefore, it is probable that the decrease in corruption perception in the Czech Republic in recent years (compare Table 1 and Graph 3 ) is reflected in the degree of institutional estrangement.

\section{Graph 5: Agreement and disagreement with the statement that political parties are corrupt - comparison over time (responses in \%) ${ }^{20}$}

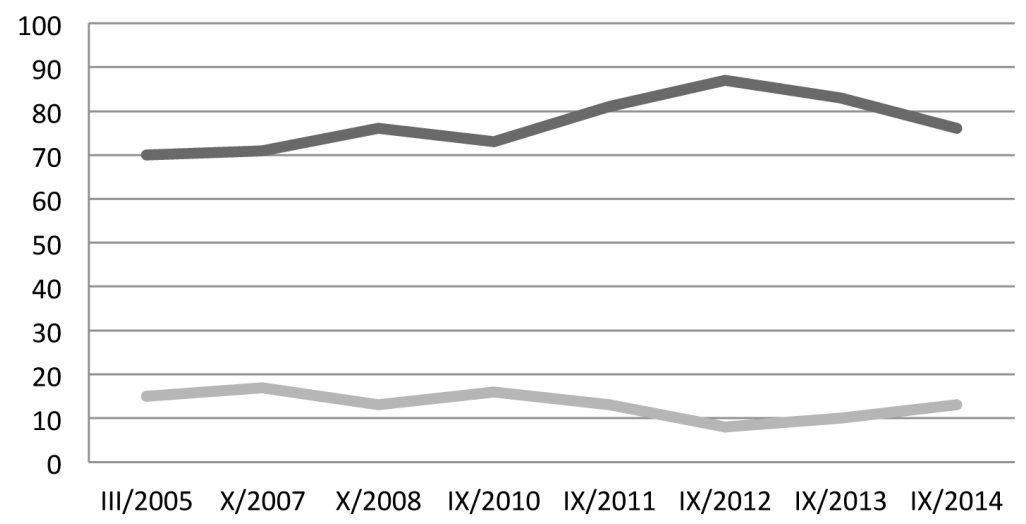

Agree Disagree

Source: CVVM (2014 b: 6)

\section{Graph 6: Attitudes toward political parties in the Czech Republic (September 2014; responses in \%)}

Political parties are interested in what people like me think only when it is election time

Political parties are corrupt

Political parties are primarily interested in the benefits and interests of its members

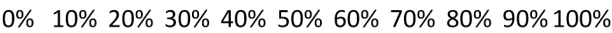

Definitely agree $\square$ Mostly agree $\square$ Mostly disagree $\quad$ Definitely disagree $\square$ Don't know

Source: modified from CVVM (2014 b: 2)

20 Numbers comprise a sum of responses of "definitely or mostly agree" and "definitely or mostly disagree". The missing \% out of $100 \%$ is comprised of "don't know" answers. 
The final dimension is the level of political dissatisfaction. The level of corruption perception is shown based on research results as one of the most important factors that influence not only overall dissatisfaction (compare with Graph 7) but specific dissatisfaction with certain institutions or political parties, mistrust in specific politicians and so forth (Linek 2010:135). One of the consequences of political dissatisfaction in terms of voting preferences can be a change in preferences for a certain party (Linek 2010: 194-199). Therefore we can assume that the high degree of corruption perception, which is in turn a source of political dissatisfaction, in some cases leads to changes in party support. This was evident in elections in 2010 and 2013, when new political parties gained success outside the party spectrum of the time, as both these parties (Věci Veřejné in 2010 and the ANO movement in 2013) placed great emphasis on the fact that they are different from the other established political formations. They both strongly highlighted corruption in their programs and the general need to replace contemporary politicians. In the case of the ANO movement, this included the slogan "We aren't like politicians - we're working hard" (anobudelip.cz 2014), while Věci Veřejné used the analogy of the fight against the "dinosaurs" in politics and the battle against corruption. This could be seen also in Věci Veřejné's symbolic firing of a cannon in the direction of the Straka Academy ${ }^{21}$ (Novinky.cz 2010; Věci Veřejné 2010). Primarily in the case of ANO, an important part of the movement's agenda was the public announcement of their "apolitical" and "non-partisan" character, which strongly corresponds to the general and widely-held belief that political parties are corrupt (Compare Graphs 5 and 6).

\section{Graph 7: Satisfaction with the functioning of democracy in the Czech Republic (October 2014; responses in \%)}

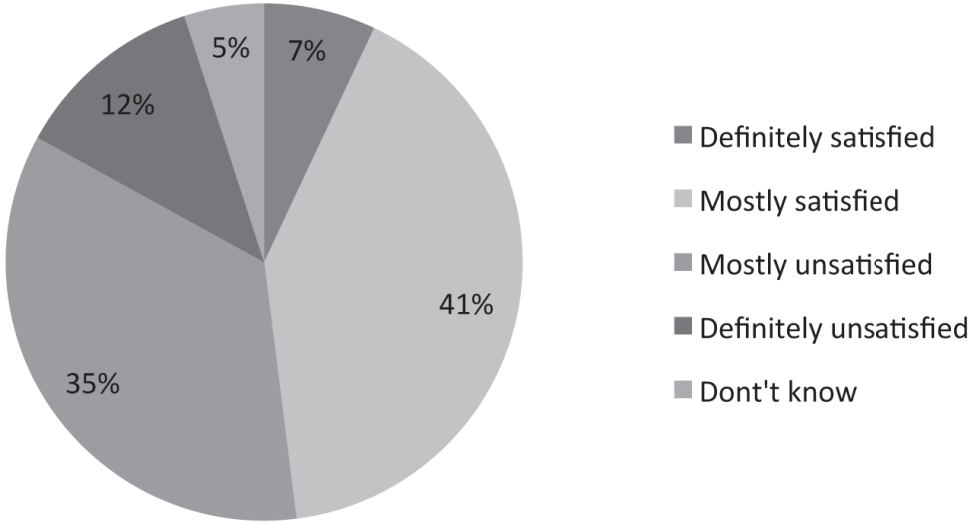

Source: CVVM (2014a: 2)

21 The Straka Academy is the seat of the Government of the Czech Republic. 
Corruption is thus significantly reflected in the approach of citizens toward the political regime at various levels. In general, corruption has extensive social consequences and leaves its mark on the state of civil society and citizens' expectations and attitudes toward it. Corruption is also connected with overall trust in society, or more exactly with the issue of social capital (compare Putnam 1993 or 2000; also Sedláčková 2012). Corruption also increases inequality (both in the economy and the accessibility of the state) and decreases the feeling of optimism and the possibility of controlling or influencing one's own life, which are two important building blocks of trust. The spread of corruption also decreases social solidarity - either directly through the influence of decreased trust or indirectly through linking social and economic inequality (Uslaner 2008a: 10). As we have already stated, the decrease of trust in the system and its institutions under any of the previously mentioned dimensions of the relationship between the individual and the system ${ }^{22}$ is caused by society (although not necessarily by the elite - compare Uslaner 2008 b: 165 and 177). This happens mainly due to the influence of large-scale corruption and not e.g. by giving small bribes to one's doctor. Small-scale corruption, however, also has its serious social and political consequences - it is something that does not happen immediately, but represents rather a gradual loss in faith in the functionality and overall meaning of official norms, i.e. in the functionality of democracy, although this does not necessarily have to (but can) be in all cases linked to the loss of the legitimacy of the whole democratic system (Linek 2010).

We can list one more serious impact of corruption. This is the impact corruption actually has "on itself", or in other words the impact of corruption on the way it is perceived. In public discourse, widespread corruption can be reproduced in public discourse. As we have already pointed out, in many post-communist countries (including the Czech Republic), society to a large degree is convinced of the corrupt nature of the elite (proof of this can be found in the generally widespread conviction that motivation for entering politics is to gain riches; Transparency International Czech Republic 2013; also compare with CPI data in Table 1 and Graph 3). The media's coverage of even alleged corruption scandals among the political elite also does its part to raise the public's belief that politicians are corrupt. Put concisely, the spread of corruption or the public's persuasion that corruption is widespread can be reflected e.g. in indicators monitoring corruption perception. The actual volume of corruption does not necessarily have to change in reality - it is enough for the public opinion to change in the favor of the idea that corruption is taking place at a higher degree

22 Confidence is not only diminished by corruption itself, but also when citizens of a country are convinced that corruption among the elite goes unpunished. Systematic corruption, which institutionalizes and immunizes itself by e.g. placing favorited individuals in key posts that are meant to combat corruption, disrupts the fairness of police investigations and the judicial process. This wholly erodes one of the basic principles of a legal state - the fact that citizens accept the laws to which they are subject. 
and thus its volume "grows". This need not apply only to corruption among high-ranking officials - similar principles help to reproduce these notions of corruption at the lowest levels of the spectrum. The belief that bribe-giving is commonplace and that "corruption is all around us", together with the help of corruption norms and the widespread opinion that giving bribes is commonly excusable and in comparison with high political corruption is negligible - all of this can impact actual existing corruption activities in the form of a self-fulfilling prophecy.

\section{Conclusion}

This paper is focused on the issue of corruption perception in the Czech Republic and the transformation of this perception over the course of the developments of the post-communist era. It also points out some of the notable tendencies linked to this issue. One of the primary factors discussed is the issue of corruption gradually permeating public debate, which applies to the discourse created among citizens, the media and the political elite. This paper also points out one of the specific segments of the political elite in greater detail based on the political party programs. During the first half of the $1990 \mathrm{~s}$, the topic of corruption was not overly publicized, and (despite proof of e.g. corruption linked to privatization) was largely overlooked and sometimes made light of by certain political elites. In this period, anti-corruption appeals began to emerge more significantly in the programs of leftist opposition, which drew these connections between corruption and privatization.

After this initial period, the issue of corruption took root in public debate. At the same time, it is interesting to note that although the period of 2002-2006 is seen as a period linked to the prevalence of corrupt activities (compare e.g. Kopeček 2013), it did not greatly affect the manner in which it was publicized. However, the number of reports referring to corruption continued to grow, culminating in 2011 and 2012 with the coverage of several scandals linked to the high political echelons across the spectrum of political parties.

The topic of corruption has transformed in terms of public debate. Recent polls (e.g. European Commission 2013) clearly show that a large portion of the Czech public is convinced that corruption is on the rise in the country. In the vast majority of polls in recent years, a great portion of the public have expressed the opinion that not only small-scale corruption is widespread, but also the corruption of the political elite and political parties, which are viewed as organizations taking part in corrupt activities and consequently attempting to cover them up. Political parties are at the same time often perceived as actors that have no realistic will to combat corruption (CVVM 2014 b; European Commission 2013 and others). This approach to political parties, which has long been present in the Czech party system, may have gained strength after 
the last parliamentary elections in 2013, during which the overall stress on the topic of corruption in election programs decreased, with even some parties like ODS leaving the issue wholly out of their program. This is also a factor that has helped new political formations (Věci Veřejné and ANO) enter the Czech Chamber of Deputies in the previous two elections, as they took a strong stance in their rhetoric against the contemporary political establishment on the issue of common corruption practices in the country.

\section{References}

Anobudelip.cz (2014): Makáme (http://www.anobudelip.cz/makame, 8. 8. 2014).

Åslund, Andras (2007): How Capitalism Was Built. The Transformation of Central and Eastern Europe, Russia, and Central Asia. Cambridge: Cambridge University Press.

Becquart-Leclercq, Jeanne (1989): Paradoxes of Political Corruption: A French View, in Heidenheimer, Arnold J. - Johnston, Michael - LeVine, Victor T., eds., Political Corruption: A Handbook, 191-210, New Brunswick: Transition Publishers.

Berger, Peter I. - Luckman, Thomas (1999): Sociální konstrukce reality. Pojednání o sociologii vědění. Brno: Centrum pro studium demokracie a kultury.

Císař, Ondřej - Petr, Tomáš (2007): Party funding in the Czech Republic, in Smilov, Daniel Tiplal, Jurij, eds., Political Finance and Corruption in Eastern Europe. The Transition Period, 71-89, Aldershot a Burlingon: Asghate.

CVVM (2014a): Názory na fungování demokracie v ČR a nedemokratické alternativy politického systému - ř́ijen 2014 (http://cvvm.soc.cas.cz/media/com_form2content/documents/c1/a7288/ f3/pd141111b.pdf, 5. 11. 2014).

CVVM (2014 b): Postoje k politickým stranám - záŕí 2014 (http://cvvm.soc.cas.cz/media/com_ form2content/documents/c1/a7280/f3/pv141029.pdf, 5. 11. 2014).

Česká televize (2011): Mor korupce. Ta naše povaha česká (http://www.ceskatelevize.cz/ porady/1100627928-ta-nase-povaha-ceska/411235100011018-mor-korupce/, 8. 8. 2014).

Dvořáková, Vladimíra (2012): Rozkl(r)ádání státu. Prague: Universum.

Dvořáková, Vladimíra (2014): (Ne)budování státu: proč se po roce 1989 stát nebudoval a proč jej nebudujeme ani nyní? Politologická revue 20(2): 19-30.

European Commission (2013): Eurobarometr 79.1 (corruption), výsledky za Českou republiku (http://ec.europa.eu/public_opinion/archives/ebs/ebs_397_fact_cz_cz1.pdf, 1. 4. 2015).

Frič, Pavol - Kabele, Jiří (1999): Korupce jako sociální fenomén, in Frič, Pavol et al., Korupce na český způsob, 9-47, Prague: G plus G.

Frič, Pavol (1999): Korupční klima v ČR, in Frič, Pavol et al., Korupce na český zpưsob, 73-115, Prague: $\mathrm{G}$ plus $\mathrm{G}$. 
Frič, Pavol (2001): Korupce - deviantní chování, nebo sociální dezorganizace? Případ české policie. Sociologický časopis 37 (1): 65-72.

Green, Penny - Ward, Tony (2004): State Crime. Governments, Violence and Corruption. London and Sterling: Pluto Press.

Haukanes, Haldis (2004): Velká dramata - obyčejné životy. Postkomunistické zkušenosti českého venkova. Prague: Sociologické nakladatelství.

Havel, Václav (1997): Projev prezidenta republiky Václava Havla k oběma komorám Parlamentu České republiky (http://www.vaclavhavel.cz/showtrans.php?cat=projevy \& val=144_projevy. html \& typ=H, 5. 5. 2014).

Holmes, Leslie (2003): Political Corruption in Central and Eastern Europe, in Bull, Martin J. - Newell, James L., eds., Corruption in Contemporary Politics, 193-206, New York, Palgrave Macmillan.

Holý, Ladislav (2010): Malý český člověk a skvělý český národ. Národní identita a postkomunistická transformace společnosti. 2nd Ed. Prague: Sociologické nakladatelství.

Howard, Marc Morjé (2002): The Weakness of Civil Society in Post-Communist Europe. Cambridge: Cambridge University Press.

Ingelhart, Donald - Catterberg, Gabriela (2002): Trends in Political Action: The Developmental Trend and the Post-Honeymoon Decline. International Journal of Comparative Sociology 43(3-5): 300-316.

Karklins, Rasma (2005): The System Made Me Do It. Corruption In Post-Communist Societies. Armonk and London: M. E. Sharpe.

Keller, Jan (2013): Kupte si svůj úřad! Salon, 1. 8. 2013: 5 and 7.

Klicperová-Baker, Martina - Feierabend, Ivo K. - Hofstetter, C. R. (1999): Post-Communist Syndrome. Theoretical Framework and Empirical Indicators, in Klicperová-Baker, Martina, ed., Ready for Democracy? Civic Culture and Civility with Focus on Czech Society, 161-184, Prague: Institute of Psychology, Academy of Sciences of the Czech Republic.

Kopeček, Lubomír (2013): Opoziční smlouvy „za kopečky“ II.: Byl pakt ČSSD a ODS z let 1998-2002 demokratickou deviací? Central European Political Studies Review 15(4): 284-299.

Kupka, Petr - Mocht́ak, Michal (2014): Aféra Nagygate mezi korupcí a organizovaným zločinem: Korupční sítě a jejich možný vliv na kvalitu demokracie v ČR. Central European Political Studies Review 16(4): 237-263.

Linek, Lukáš - Outlý, Jan (2008): Czech Republic: Is It Possible To Buy Political Stability?, in Roper, Steven D. - Ikstens, Janis, eds., Public Finance and Post-Communist Party Development, 77-94, Aldershot, Hampshire: Asghate.

Linek, Lukáš (2010): Zrazení snu? Struktura a dynamika postojů k politickému režimu a jeho institucím a jejich důsledky. Prague: Sociologické nakladatelství.

Matějka, Ondřej (2014): Jak probíhá občanské vzdělávání v ČR? Conference X. brněnské politologické sympozium (conference contribution). Brno: FSS MU.

Miller, William M. - Grodeland, Ase B. - Koskechkina, Tatyana Y. (2001): A Culture of Corruption? Coping with Government in Post-Communist Europe. Budapest: Central European University Press. 
Možný, Ivo (2009): Proč tak snadno. Některé rodinné důvody sametové revoluce. Sociologický esej. 3rd Ed. Prague: Sociologické nakladatelství.

Müller, Karel B. (2012a): Kmotři, dárky a moderní byrokracie: dílčí shrnutí a dvě kritické poznámky k sociálním studiím lobbingu. Acta Fakulty filozofické Západočeské univerzity v Plzni, 8(3): 81-101.

Müller, Karel B. (2012 b): Politická sociologie. Politika a identita v proměnách modernity. 2nd Ed. Pilsen: Vydavatelství a nakladatelství Aleš Čeněk.

Naxera, Vladimír (2014): Stranická patronáž a její vztah ke korupci a klientelismu: Teoretický koncept a nástin uplatnění v postkomunistickém prostředí. Central European Political Studies Review 16(4): 264-287.

Naxera, Vladimír (2015): Zobrazování korupce v programatice českých politických stran v průběhu postkomunistického vývoje. Politické vedy 18(1): 57-85.

Novinky.cz (2010): Věci veřejné začaly kampaň výstřelem z děla na Strakovu akademii (http:// www.novinky.cz/domaci/198058-veci-verejne-zacaly-kampan-vystrelem-z-dela-na-strakovu-akademii.html).

Pšeja, Pavel (2005): Stranický systém České republiky. Politické strany a jejich vývoj 1989-1998. Brno: Centrum pro studium demokracie a kultury.

Putnam, Robert (1993): Making Democracy Work: Civic Traditions in Modern Italy. Princeton: Princeton University Press.

Putnam, Robert (2000): Bowling Alone. The Collapse and Revival of American Community. New York: Simon \& Schuster.

Reed, Quentin (1999a): Korupce v privatizaci českou cestou, in Frič, Pavol et al., Korupce na český způsob, 159-204, Prague: G plus G.

Reed, Quentin (1999 b): Politická korupce v postkomunistické společnosti, in Frič, Pavol et al., Korupce na český způsob, 116-158, Prague: G plus G.

Sajó, András (1998): Corruption, Clientelism, and the Future of the Constitutional State in Eastern Europe. East European Constitutional Review 7(2): 37-46.

Sandholtz, Wayne - Taagepera, Rein (2005): Corruption, Culture, and Communism. International Review of Sociology 15(1): 109-131.

Scott, James C. (1972): Comparative Political Corruption. Engelwood Cliffs: Prentice-Hall, Inc.

Sedláčková, Markéta (2012): Důvěra a demokracie. Přehled sociologických teorií důvěry od Tocquevilla po transformaci v postkomunistických zemích. Prague: Sociologické nakladatelství.

Transparency International (n.d.): Corruption Perception Index (http://www.transparency.org/ research/cpi/overview, 8. 8. 2014).

Transparency International Česká republika （2013): Mapování korupce (http://www.transparency.cz/co-delame/temata/mapovani-korupce/, 8. 8. 2014).

Uslaner, Eric M. (2008a): Coping and Social Capital: the Informal Sector and the Democratic Transition, in Lewandowski, Joseph D. - Znoj, Milan, eds., Trust and Transitions: Social Capital in a Changing World, 3-27, Newcastle upon Tyne: Cambridge Scholars Publishing. 
Uslaner, Eric M. (2008 b): Corruption, Inequality, and the Rule of Law. Cambridge: Cambridge University Press.

Věci veřejné (2010): Politický program (https://www.veciverejne.cz/program.html, 5. 3. 2011).

Vráblíková, Kateřina (2009): Politická participace a její determinanty v postkomunistických zemích. Sociologický časopis 45(5): 867-897.

PhDr. Vladimír Naxera, Ph.D. is a junior lecturer, Department of Politics and International Relations, Faculty of Philosophy and Arts, University of West Bohemia. E-mail:vmaxera@kap.zcu.cz. 